\title{
Mathematical Model for Timber Decay in Contact with the Ground Adjusted for the State of São Paulo, Brazil
}

\author{
Roberto Ramos de Freitas*, Julio Cesar Molina, Carlito Calil Júnior \\ School of Engineering of São Carlos, University of São Paulo - USP, \\ Av. Trabalhador Sãocarlense, 400, CEP 13566-590 São Carlos, SP, Brazil
}

Received: July 20, 2009; Revised: May 5, 2010

\begin{abstract}
At this moment, the environmental sustainability has been incorporated to all branches of activity more and more; timber seems to be the best alternative in civil construction. Nevertheless, for a correct and better usage of timber as a structural material, it is necessary to have a higher degree of knowledge not only of the structural mechanical behavior, but also about its durability and service life. With help from mathematical models the service life of the timber structures can be foreseen, by obtaining the "Climate Indices", that show comparatively among the studied regions, which ones have a higher or lesser propensity of being attacked by fungi. In this paper, utilizing climatologic data from several cities of the State of São Paulo - Brazil was determined through numerical analysis and statistics, the simplification of one aggressive model to timber in contact with the ground, being this model adjusted to the State of São Paulo. The simplified model of timber degradation can be used to quantity the effect of the environment in the process of decay for the regional climatic conditions.
\end{abstract}

Keywords: timber, decay model, durability

\section{Introduction}

There's no doubt that wood is one of the most versatile materials that nature puts at the disposal of humankind. Wood has been used for millions of years to fulfill the needs that come from a society that is each time thirstier for new sources of energy and raw materials.

With many possibilities to utilize the wood, both in civil construction and in industry, round timbers and ties (stakes, shoring, poles and columns, etc.), represent some of the most efficient uses of our natural forest resources, demanding a minimum of processing between the harvesting of the tree and selling the structural commodity. Because these products are somewhat cheap to produce, compared to gluelam, steel and concrete articles, they are more often than not used far and wide in the United States ${ }^{1}$.

No material is inherently durable due to the environmental and micro-structural interactions consequently, the material properties change as time passes by, admitting that the limit of use has been reached, when its properties decay, under certain conditions of usage, up to a point that to keep on using this material is considered unsafe or anti-economical ${ }^{2}$.

Life service gives the measurement of time of a product and its materials, in which normal usage conditions (that is, if it's not put into stressful conditions beyond acceptable limits) can last conserving its own capacities (service, output, etc) and its own behavior, in a pre-established standard level ${ }^{3}$.

\section{Decay}

The biological nature of the wood makes it susceptible to the aggressions of fungi and insects, however the drying and the preservation of a side, and the association to other materials in the places of constructions that are more vulnerable to attacks than others, make the timber structures as durable as steel or concrete, since its conception respects certain rules of protection of the material ${ }^{4}$.
The main groups of xylophagan organisms are the bacteria, fungi, insects, clams, crustaceans ${ }^{5}$, being that the decay fungi are responsible for deep alterations in the physical and mechanical properties of the wood, due to gradual destruction of the molecules that constitute its cellular walls ${ }^{5,6}$.

The decay affects initially the stiffness, the ability of the material to resist impacts generally, being followed by reduction of the resistance the static bending, and finally all the properties of resistance of the wood seriously are reduced ${ }^{7}$.

After having established the layer of fungi, the speed of growth of these is dependant primarily of the humidity and temperature, Figure 1a. The conditions of growth of the fungi vary a lot from one species to another, but as a general rule, it has been observed that for temperatures below $5{ }^{\circ} \mathrm{C}$ the fungi had lived dormant, while for temperatures above $65^{\circ} \mathrm{C}$ these will be dead in a few hours ${ }^{8}$.

As for the humidity, the speed of growth of the fungi is extremely low for values of humidity below the fiber saturation point, Figure 1b, the lesser humidity in which the fungi grow that has been observed is $19 \%$, and the superior limit corresponds to $80 \%$ humidity, where the cell cavities are saturated ${ }^{8}$.

\section{Models of Decay}

A model for the decay of parts in contact with the ground was proposed based in small monitored stakes for more than 30 years in Australia9. Such model considers that a time (lag) for the beginning of the decay process exists, which after the beginning evolves in a speed (reason "r") constant, being able to occur a new initial time and stop the decay with maintenance accomplishment, Figure 2.

From the data obtained in the study, a mathematical model for the decay of wood in contact with the ground was developed, determining the "Climate Index" $\mathrm{I}_{\mathrm{ig}}$, through functions $\mathrm{f}\left(\mathrm{R}_{\text {mean }}\right)$ and $\mathrm{g}\left(\mathrm{T}_{\text {mean }}\right)$, 
which are dependant of the Annual Average Precipitation - $\mathrm{R}_{\text {mean }}$ and of the Annual Average Temperature - $\mathrm{T}_{\text {mean }}$, respectively. Being $\mathrm{N}_{\mathrm{dm}}$ the number of dry months per year, defined as dry month that one in which the average precipitation is lesser or equal to $5 \mathrm{~mm}^{[9]}$.

$$
\begin{gathered}
I_{\text {ig }}=f\left(R_{\text {mean }}\right)^{0,3} \times g\left(T_{\text {mean }}\right)^{0,2} \\
f\left(R_{\text {mean }}\right)=\left\{\begin{array}{ll}
0 & \text { (Equation 1) } \\
f_{0}\left(R_{\text {mean }}\right) \times\left(1-\frac{N_{d m}}{6}\right) R_{\text {mean }} \leq 250 \text { mm ou } N_{d m}>6 & \text { se } R_{\text {mean }}>250 \text { mm e } 0 \leq N_{d m} \leq 6
\end{array}\right. \text { (Equation 2) } \\
f_{0}\left(R_{\text {mean }}\right)=10 \times\left[1-e^{-0,001\left(R_{\text {mean }}-250\right)}\right] \\
g\left(T_{\text {mean }}\right)= \begin{cases}0 & \text { se } T_{\text {mean }} \leq 5^{\circ} \mathrm{C} \\
-1+0,2 \times T_{\text {mean }} & \text { se } 5<T_{\text {mean }} \leq 20^{\circ} \mathrm{C} \text { (Equation 4) } \\
-25+1,4 \times T_{\text {mean }} & \text { se } T_{\text {mean }}>20^{\circ} \mathrm{C}\end{cases}
\end{gathered}
$$

As for the influence of the types of wood present in one pole, it is admitted the project considered in Figure 3, where the rates of decay are shown schematically for the types of $\operatorname{wood}^{9}$. The list of used abbreviations is presented in the Appendix 1.

To determine the initial time for the installation of the decay process (lag) and the decay rate (r), the following equations and the parameters of Table 1 are adopted.

- Outer heartwood

$$
r_{\text {un, heart, } \text { stake }}=A \times I_{\text {ig }}
$$

(Equation 5)

- Corewood

$$
\operatorname{lag}_{\text {un, } \text { core, } \text { stake }}=0,3 \times \operatorname{lag}_{\text {un, heart }, \text { stake }}
$$

(Equation 6)

$$
r_{\text {un, } \text { core, } \text { stake }}=3 \times r_{\text {un, }} \text { heart }, \text { stake }
$$

- Sapwood

$\operatorname{lag}_{\text {un, sap, stake }}=0,5 \times \operatorname{lag}_{\text {un, heart, dc } 4, \text { stake }}$

(Equation 8)

$r_{\text {un, sap, stake }}=2 \times r_{\text {un, heart, }}$ dc 4 , stake

(Equation 9)

\subsection{Being}

$\operatorname{lag}_{\text {un, heart, dc4, stake: }}$ the initial time of decay for the external heartwood species of durability class 4 ;

$r_{u n, \text { heart, dc4, stake }}$ decay rate for the external heartwood species of durability class 4 ;

\section{Studied Region}

São Paulo is one of the states of Brazil, being located approximately between the longitudes $44^{\circ}$ and $53^{\circ} \mathrm{W}$ and latitudes $20^{\circ}$ and $25^{\circ} \mathrm{S}$, a small part is below of the Capricorn Tropic (23⒉ $07^{\prime}$ ' S). Thus most of the State of São Paulo this located in a tropical region. Figure 4 shows the localization of the State of São Paulo in Brazil.

The State of São Paulo has a large extent of mountainous areas of altitude, where the rain is sufficiently mild and thus it can generally be classified as tropical of altitude, where the rain is abundant, over all in the station stowage, making the climate humid tropical ${ }^{10}$.

According to the climatic classification of Koeppen, the State of São Paulo encloses six distinct climatic types, all corresponding to the humid climates. The type that corresponds to the biggest area is the

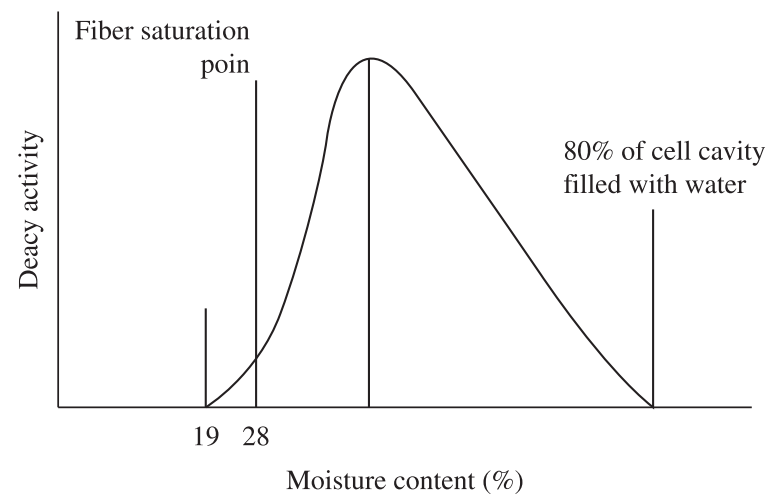

(a)

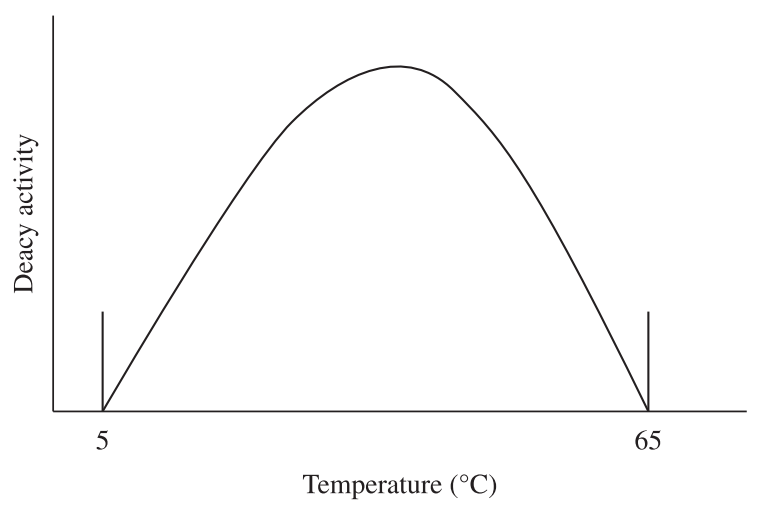

(b)

Figure 1. Functions idealized for two parameters of decay ${ }^{8}$.

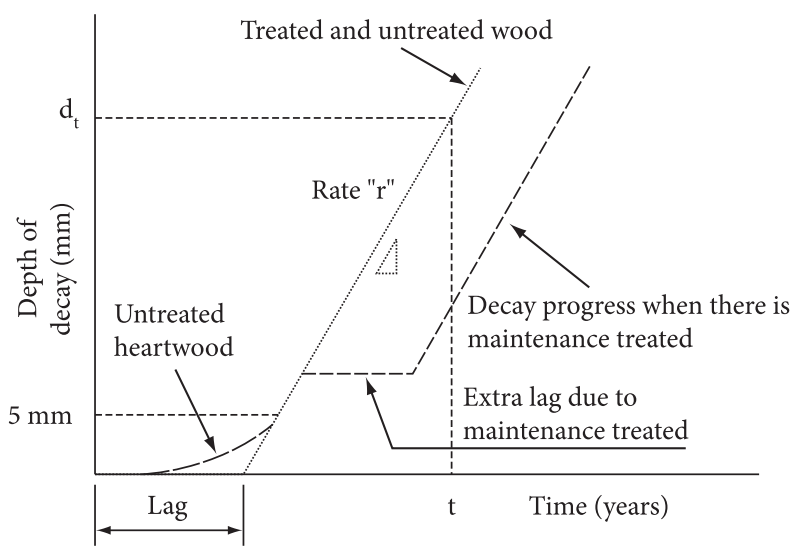

Figure 2. Relationship of idealized decay ${ }^{9}$.

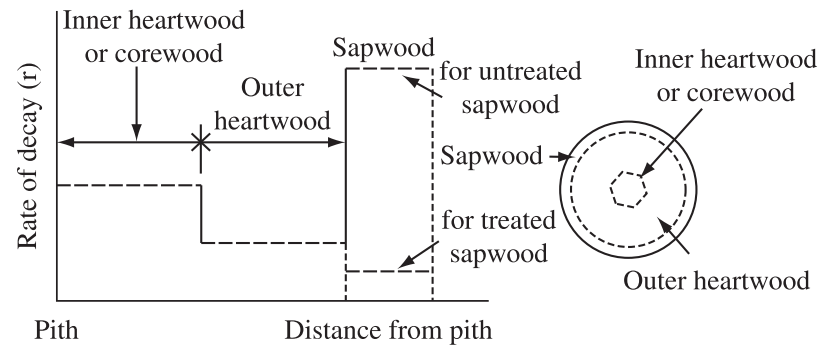

Figure 3. Illustrative scheme of the relative decay rate of different types of wood $^{9}$. 


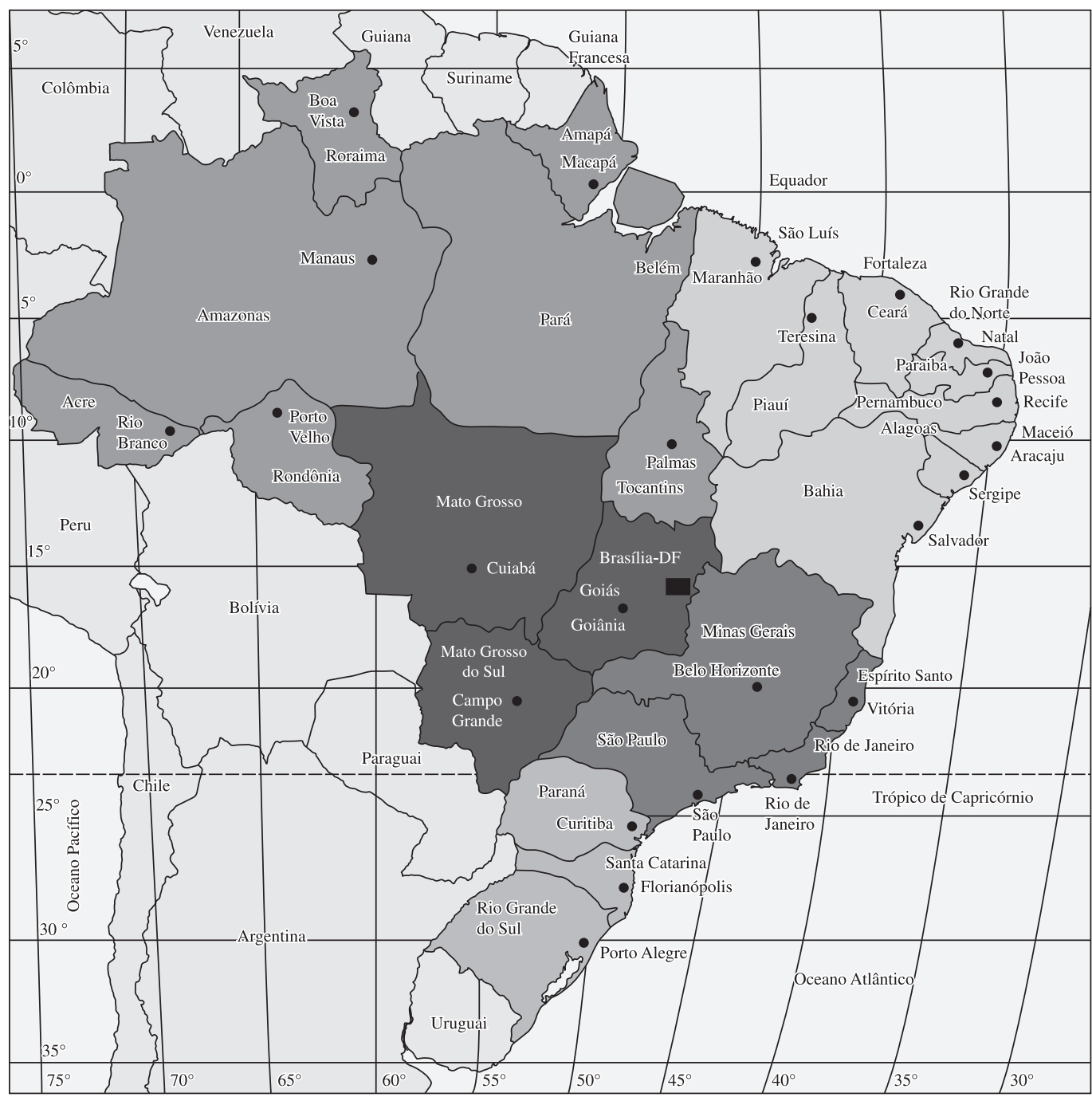

Figure 4. Localization of São Paulo State.

Table 1. Parameters of decay for external not treated heartwood ${ }^{9}$.

\begin{tabular}{ccc}
\hline $\begin{array}{c}\text { Durability class } \\
\text { (AS 5604-2005) }\end{array}$ & $\mathrm{A}$ & \multicolumn{2}{c}{$\begin{array}{c}\text { Initial time } \\
\text { (years) }\end{array}$} \\
\hline Class 1 & 0.20 & 6 \\
Class 2 & 0.55 & 4 \\
Class 3 & 0.80 & 2 \\
Class 4 & 1.85 & 1 \\
\hline
\end{tabular}

Table 2. Statistics of the climatic data.

\begin{tabular}{lccc}
\hline Statistics & $\begin{array}{c}\text { Temperature } \\
\left({ }^{\circ} \mathrm{C}\right)\end{array}$ & $\begin{array}{c}\text { Annual } \\
\text { Precipitation }(\mathrm{mm})\end{array}$ & $\begin{array}{c}\mathrm{N}_{\mathrm{dm}}-\mathrm{dry} \\
\text { months }\end{array}$ \\
\hline Mean & 22.6 & 1446 & 0.8 \\
Minimum & 15.1 & 1165 & 0.0 \\
Maximum & 25.7 & 2514 & 1.9 \\
Amplitude & 10.6 & 1349 & 1.9 \\
\hline
\end{tabular}

Table 3. Statistics of the climatologic data.

\begin{tabular}{ll}
\hline Statistics & $\mathrm{I}_{\mathrm{ig}}$ \\
\hline Mean & 2.48 \\
Minimum & 2.04 \\
Maximum & 2.5 \\
Amplitude & 0.81 \\
\hline
\end{tabular}

Considering the classes of aggressiveness form the initial model ${ }^{17}$, Table 4 shows the distribution of cities in relation to this classification.

Table 4. Representative climatic Index for four classes of aggressiveness.

\begin{tabular}{ccc}
\hline Region of decay & Representative $\mathrm{I}_{\mathrm{ig}}$ & Number of cities \\
\hline A & 0.5 & 0 \\
B & 1.5 & 0 \\
C & 2.5 & 49 \\
D & 3.0 & 53 \\
\hline
\end{tabular}


Cwa, being all the central part of plateaus characterized for the tropical climate of altitude. Some mountain range areas, with the mild summer, are classified in the $\mathrm{Cwb}$ type. The lowest regions, the northwest, situated in the neighborhoods of the rivers Paraná and Grande, hotter, belong to the Aw type. To the south of plateaus, to the edges of the river Paranapanema, and the valley of the river Ribeira de Iguape, there are bands of tropical climate Cfa. The mountain range areas, higher, of the mountain ranges of the Sea and the Mantiqueira, with mild summer and rainy seasons all year round, have the classified climate as $\mathrm{CFb}$. Finally, the seaside band receives the Af classification ${ }^{10}$.

Using climatologic data supplied by IAC - Agronomic Institute of Campinas, the values of $\mathrm{I}_{\mathrm{ig}}$ were determined according to the initial model $^{9}$, and the simplified $\mathrm{I}_{\mathrm{ig}}^{\mathrm{g}}$, according to the model proposed here.

Even though data have been supplied from 113 meteorological stations, situated in several cities in the State of São Paulo, the determination of the values of $\mathrm{I}_{\mathrm{ig}}$ and $\mathrm{I}_{\mathrm{ig} \text {; simplified }}$ was carried through only for the stations that possessed a minimum period of reading, until the moment of the attainment of the data, of at least 5 years, thus 11 weather forecast stations had been discarded of the study. This measurement contributes so that little representative values are not obtained, in function of annual variations of the climate. Table 2 shows the descriptive statistics of the climatic data of the studied cities.

Figures 5 to 7 show the distributions of absolute frequency for the data of Temperature, Annual Precipitation and Dry Months. The normal distribution curve is shown next to the histogram.

\section{Application of Leicester's Model}

Table 3 shows the descriptive statistics for the obtained values with the application of the climatologic data to Leicester's model ${ }^{9}$.

Considering the classes of aggressiveness form the initial model ${ }^{17}$, Table 4 shows the distribution of cities in relation to this classification.

Table 5 shows the descriptive statistics for the population variables of $\mathrm{I}_{\mathrm{ig}<2.50}$ e $\mathrm{I}_{\mathrm{ig}>2.50^{\text {* }}}$.

Intending to verify if the cities classified by the decay regions according to Table 5 have different temperature populations, precipitation and dry months, the F-test of variables is carried through (using Snedecor's distribution), dividing them into two populations; cities with $\mathrm{I}_{\mathrm{ig}}$ smaller than $2.50\left(\mathrm{I}_{\mathrm{ig}<2.50}\right)$ and cities with $\mathrm{I}_{\mathrm{ig}}$ greater than $2.50\left(\mathrm{I}_{\mathrm{ig}>2.50}^{\mathrm{ig}}\right)$.

Adopting a significant level of $5 \%(\alpha=0.05)$ for the F-test we have that:

- F-Test for temperature

$H_{0}$ : the variance of temperatures for $I_{i g<2.50}$ and $I_{i g>2.50}$ are equal.

$H_{1}$ : the variance of temperatures for $I_{i g}<2.50$ and $I_{i g}>2.50$ are not equal.

Fobtained: 2.845 Fcritic: 1.596

P-Value: 0.0001

Conclusion: reject $\mathrm{HO}$

- F-Test for precipitation

$H_{0}$ : the variance of precipitations of $I_{i g<2.50}$ and $I_{i g}>2.50$ are equal.

$H_{1}$ : the variance of precipitations of $I_{i g}<2.50$ and $I_{i g}>2.50$ are not equal.

Fobtained: 3.307 Fcritic: $1.604 \quad P$-Value: 0.000025

Conclusion: reject $\mathrm{HO}$

- F-Test for dry months

$H_{0}$ : the variance of dry months of $I_{i g<.2 .50}$ and $I_{i g}>2.50$ are equal.

$H_{1}$ : the variance of dry months of $I_{i g<2.50}$ and $I_{i g}>2.50$ are not equal.

Fobtained: 1.220 Fcritic: $1.604 \quad P$-Value: 0.244

Conclusion: not reject $\mathrm{HO}$
There are no statistical evidence that the temperature populations

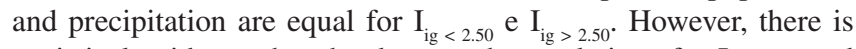
statistical evidence that the dry month populations for $\mathrm{I}_{\mathrm{ig}<2.50}$ and $\mathrm{I}_{\mathrm{ig}>2.50}$ equal.

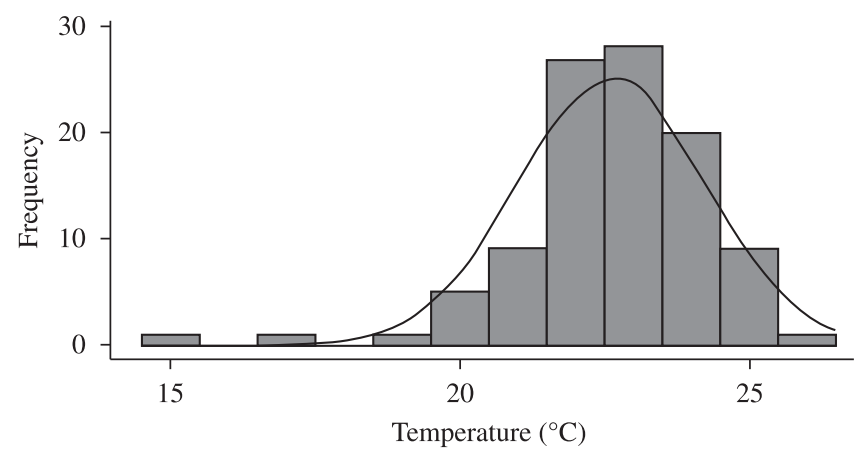

Figure 5. Absolute frequency histogram of the average temperatures for the cities of São Paulo State.

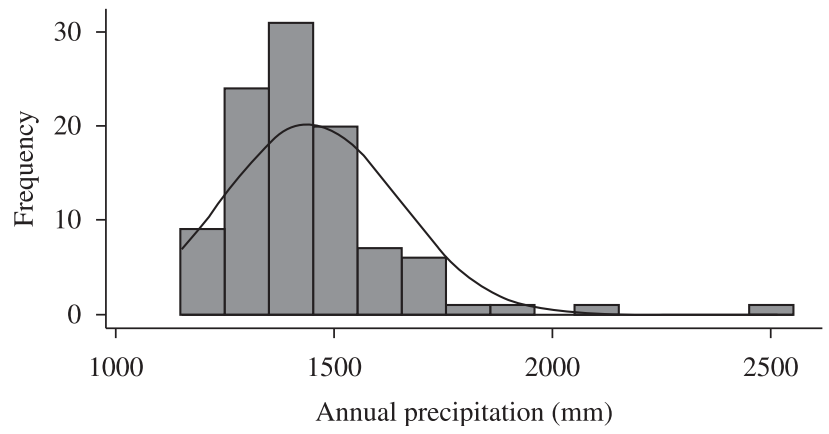

Figure 6. Absolute frequency histogram of the annual precipitations for the cities of São Paulo State.

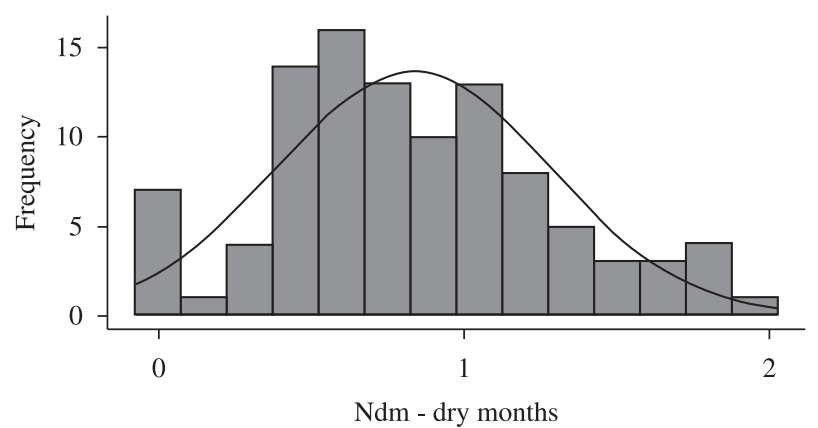

Figure 7. Absolute frequency histogram of the dry months for the cities of São Paulo State.

Table 5. Descriptive statistics for the population variables of $I_{\mathrm{ig}}$.

\begin{tabular}{|c|c|c|c|c|c|c|}
\hline \multirow{2}{*}{$\begin{array}{c}\text { Statistics } \\
-\end{array}$} & \multicolumn{2}{|c|}{$\begin{array}{c}\text { Temperature } \\
\left({ }^{\circ} \mathrm{C}\right)\end{array}$} & \multicolumn{2}{|c|}{$\begin{array}{l}\text { Precipitation } \\
(\mathrm{mm})\end{array}$} & \multicolumn{2}{|c|}{$\begin{array}{c}\mathrm{N}_{\mathrm{dm}}-\mathrm{dry} \\
\text { months }\end{array}$} \\
\hline & $\mathrm{I}_{\mathrm{ig}<2.50}$ & $\mathrm{I}_{\mathrm{ig}>2.50}$ & $\mathrm{I}_{\mathrm{ig}<2.50}$ & $\mathrm{I}_{\mathrm{ig}>2.50}$ & $\mathrm{I}_{\mathrm{ig}<2.50}$ & $\mathrm{I}_{\mathrm{ig}>2.50}$ \\
\hline Mean & 21.5 & 23.6 & 1405 & 1483 & 0.87 & 0.80 \\
\hline Minimum & 15.1 & 21.5 & 1165 & 1174 & 0.25 & 0.00 \\
\hline Maximum & 24.1 & 25.7 & 1726 & 2514 & 1.88 & 1.75 \\
\hline
\end{tabular}


It can be concluded that the variable $\mathrm{N}_{\mathrm{dm}}$ (dry months) is not for this set of data in analysis it isn't a variable of significant contribution for determining $\mathrm{I}_{\mathrm{ig}}$.

\section{Proposition of Model}

The simplification proposed is the withdrawal of the variable " $\mathrm{N}_{\mathrm{dm}}$ - dry months", which is the hardest to attain. This proposal is justified, since carrying through the F-test for this variable for the populations of $\mathrm{I}_{\mathrm{ig}}<2.50$ and $\mathrm{I}_{\mathrm{ig}}>2.50$, did not give statistical evidence of difference between this data set.

The simplification is initiated only with the withdrawal of the variable $\mathrm{N}_{\mathrm{dm}}$ of the model. The model to be used initially is given bellow:

\subsection{Leicester's simplified model}

$$
\begin{aligned}
& I_{\text {ig; simplified }}=f\left(R_{\text {mean }}\right)^{0,3} \times g\left(T_{\text {mean }}\right)^{0,2} \\
& f\left(R_{\text {mean }}\right)= \begin{cases}0 & \text { Se } R_{\text {mean }} \leq 250 \mathrm{~mm} \\
f_{0}\left(R_{\text {mean }}\right) & \text { Se } R_{\text {mean }}>250 \mathrm{~mm}\end{cases} \\
& f_{0}\left(R_{\text {mean }}\right) 10 \times\left[1-e^{-0,001\left(R_{\text {mean }}-250\right)}\right] \\
& g\left(T_{\text {mean }}\right)= \begin{cases}0 & \text { Se } T_{\text {mean }} \leq 5^{\circ} \mathrm{C} \\
-1+0,2 \times T_{\text {mean }} & \text { Se } 5<T_{\text {mean }} \leq 20^{\circ} \mathrm{C} \\
-25+1,4 \times T_{\text {mean }} & \text { Se } T_{\text {mean }}>20^{\circ} \mathrm{C}\end{cases}
\end{aligned}
$$

Table 6 compares the descriptic statistics of $\mathrm{I}_{\mathrm{ig}}$ e $\mathrm{I}_{\mathrm{ig}}$; simplified.

Figure 8 compares the dispersion of the values of $\mathrm{I}_{\mathrm{ig}}$ and $\mathrm{I}_{\mathrm{ig} \text {; simplified }}$ A positive displacement (increase of the values) of the population of data as well as of the average can be observed.

To verify proposal of the simplification done, it is necessary to observe if there is a correlation between the values of the current model and the simplified model. Figures 9 and 10 show the regression and the residues of the regression for $\mathrm{I}_{\mathrm{ig}}$ and $\mathrm{I}_{\mathrm{ig} \text {; simplified }}$, respectively. The value of $\mathrm{r}^{2}$ - coefficient of determination for this regression is of $83.3 \%$.

From Figure 10 it is observed that the correlation between $\mathrm{I}_{\mathrm{i}}$ and $\mathrm{I}_{\mathrm{ig} \text {; simplified }}$ does not present independence of errors in function of $\mathrm{I}_{\mathrm{ig} \text {; simplified }}$. This characteristic can be explained considering that for the exact same value of the reduction factor $\left(1-\mathrm{N}_{\mathrm{dm}} / 6\right)$, the difference between the value of $\mathrm{I}_{\mathrm{ig}}$ and $\mathrm{I}_{\mathrm{ig} \text {; simplified }}$ increases proportionally to the second variable.

Adopting the same classification of aggressiveness already used ${ }^{9}$, Table 7 shows the distribution of $\mathrm{I}_{\mathrm{ig} \text {; simplified }}$.

Table 8 shows the descriptive statistics for the climatologic indices of the populations of $\mathrm{I}_{\mathrm{ig}}$; simplified.

The F-test is carried through to identify if it is possible to consider that the two populations $\mathrm{I}_{\mathrm{ig}}$ and $\mathrm{I}_{\mathrm{ig} \text {; simplified }}$ are equal. Thus, for $\alpha=0.5$ we have:

- F-Test $\mathrm{I}_{\mathrm{ig}}$ e $\mathrm{I}_{\mathrm{ig} ; \text { simplified }}$

$H_{0}$ : the variances of $I_{i g}$ and $I_{i g ; \text { simplified }}$ are equal.

$H_{1}$ : the variances of $I_{i g}$ and $I_{i g ;}$ simplified are not equal.

Fobtained: 1.087 Fcritic: $1.389 \quad$ P-Value: 0.338

\section{Conclusion: not reject $\mathrm{HO}$}

From the test above it is possible to verify statistical evidences that the populations of $\mathrm{I}_{\mathrm{ig}}$ and $\mathrm{I}_{\mathrm{ig} \text {; simplified }}$ are equal.
As previously, the F-test is carried through between the populations of temperature and precipitation, verifying if the populations of these parameters differ in $\mathrm{I}_{\mathrm{ig} \text {; simplified }}$, dividing them again in two populations; cities with $\mathrm{I}_{\mathrm{ig} \text {; simplified }}$ smaller than $2.50\left(\mathrm{I}_{\mathrm{ig} \text {; simplified <2.50) }}\right)$ and cities with $\mathrm{I}_{\mathrm{ig} \text {; simplified }}$ greater than $2.50\left(\mathrm{I}_{\mathrm{ig} \text {; simplified }>2.50}\right)$. This way, for a level of significance of $5 \%(=$ the 0.05$)$ we have that:

- F-Test for temperature

$H_{0}$ : the variance of temperatures of $I_{i g ; \text { simplified }<2.50}$ and $I_{i g ; \text { simplified }}>2.50$ are equal.

$H_{1}$ : the variance of temperatures of $I_{i g ;}$ simplified $<2.50$ and $I_{i g ;}$ simplified $>2.50$ are not equal.

Fobtained: 2.517 Fcritic: $1.639 \quad P$-Value: 0.0001

Conclusion: reject $\mathrm{HO}$

- F-Test for precipitation

$H_{0}$ : the variance of precipitations of $I_{i g ; \text { simplified }<2.50}$ and $I_{i g ; \text { simplified }>2.50}$ are equal.

$H_{1}$ : the variance of precipitations of $I_{i g ;}$ simplified $<2.50$ and $I_{i g \text {; simplified }>2.50}$ are not equal.

Fobtained: 2.062 Fcritic: 1.766

P-Value: 0.019

\section{Conclusion: reject $\mathrm{HO}$}

There are no statistical evidence that the temperature populations and precipitation are equal for the populations $I_{\mathrm{ig} \text {, simplified }<2.50}$ and $\mathrm{I}_{\mathrm{ig} ; \text { simplified }>2.50^{\circ}}$

One concludes that the withdrawal of the $\mathrm{N}_{\mathrm{dm}}$ variable of the model proposed by Leicester, did not influence the variables temperature and precipitation, in determination of the aggressiveness index, since the population of the values of these variables, are still distant for $\mathrm{I}_{\mathrm{ig} \text {; simplified }<2.50}$ and $\mathrm{I}_{\mathrm{ig} \text {; simplified }>2.50}$, for the studied data set.

\subsection{Analysis of regressions}

Completing a regression between the values of $\mathrm{I}_{\mathrm{ig}}$ and $\mathrm{I}_{\mathrm{ig} \text { : simplified }}$ for the ten most aggressive cities according to $\mathrm{I}_{\mathrm{ig}}$, a low value of the determination coefficient, $\mathrm{r}^{2}=36.6 \%$ is obtained, Figure 11 .

However, the regression between the values of $\mathrm{I}_{\mathrm{ig}}$ and $\mathrm{I}_{\mathrm{ig} \text {; simplified }}$ for the ten less aggressive cites according to $I_{i g}$, a high value of determination coefficient, $\mathrm{r}^{2}=95.5 \%$ is obtained, Figure 12 .

The equation of the straight line it is given by:

$$
y=a x+b
$$

(Equation 14)

So that the values of the $\mathrm{x}$ coordinate are equal to the ones of the y coordinate, it is necessary that the linear coefficient (a) be null, and that the value of angular coefficient (b) be equal to 1 , as the Equation 15.

$$
y=0+1 \times x
$$

(Equation 15)

The greater the value of the linear coefficient (a) and that of the angular coefficient (b) in module, greater the distance the straight line is from the identity $(\mathrm{y}=\mathrm{x})$.

Table 9 compares the values of the linear and angular coefficients of the regression carried through previously. It is verified that the values of the coefficient is very close to the values for the identity only for regression to the smaller $\mathrm{I}_{\mathrm{ig}}$ values.

Withdrawing the $\mathrm{N}_{\mathrm{dm}}$ variable (dry months), the populations of $I_{\mathrm{ig}}$ and $\mathrm{I}_{\mathrm{ig} \text {; simplified }}$ are not significantly different. However, the greater the value of $I_{i g}$, greater is the difference between the values of $I_{i g}$ and $\mathrm{I}_{\mathrm{ig} \text {; simplified }}$ obtained. From Figure 9, it can be observed that up to

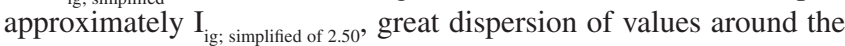
regression straight line does not exist, notwithstanding above this 


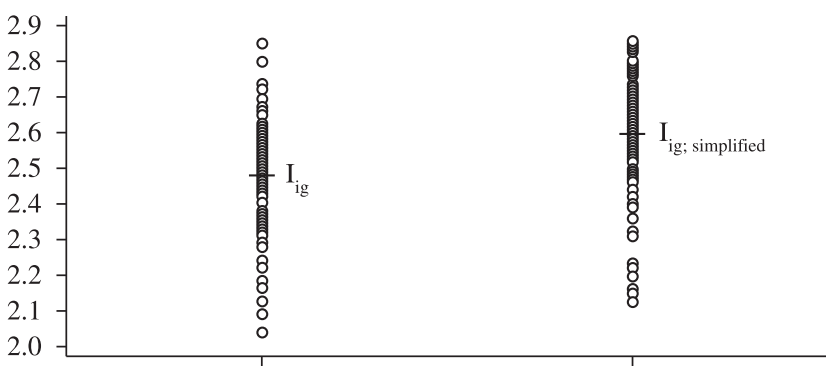

Figure 8. Populations of $\mathrm{I}_{\mathrm{ig}}$ and $\mathrm{I}_{\mathrm{ig} \text {; simplified }}$.

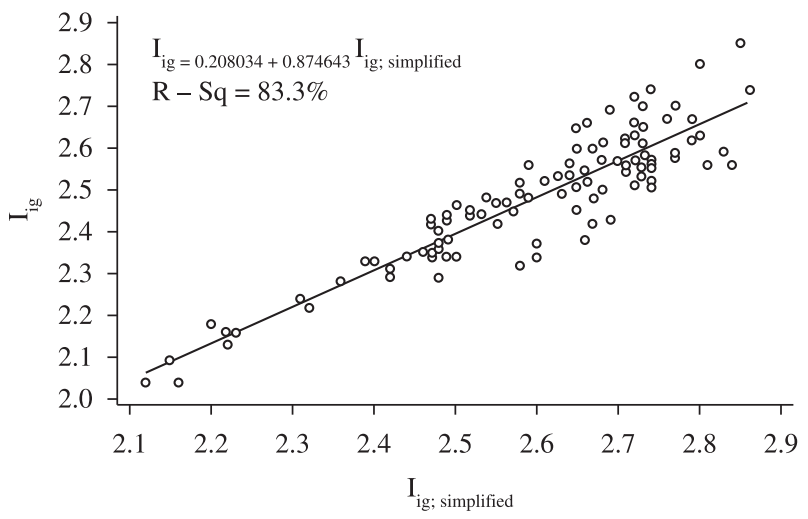

Figure 9. Regression $I_{\mathrm{ig}} \times \mathrm{I}_{\mathrm{ig} \text {; simplified }}$

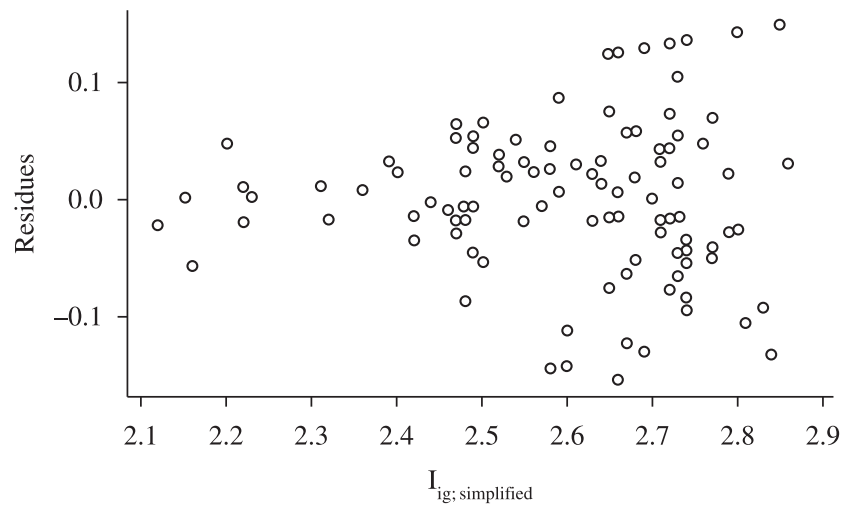

Figure 10. Resídues $\times \mathrm{I}_{\mathrm{ig} ; \text { simplified }}$

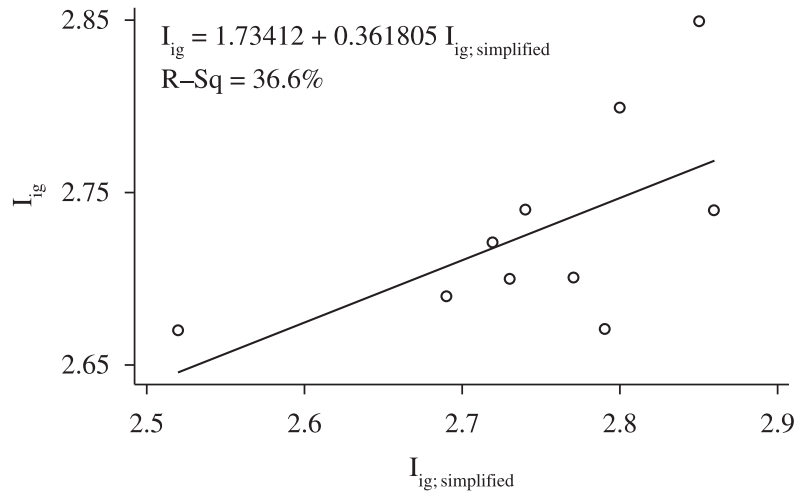

Figure 11. Regression between $\mathrm{I}_{\mathrm{ig}}$ and $\mathrm{I}_{\mathrm{ig} \text {; simplified }}$ for the cities of the greatest values of $I_{i g}$.

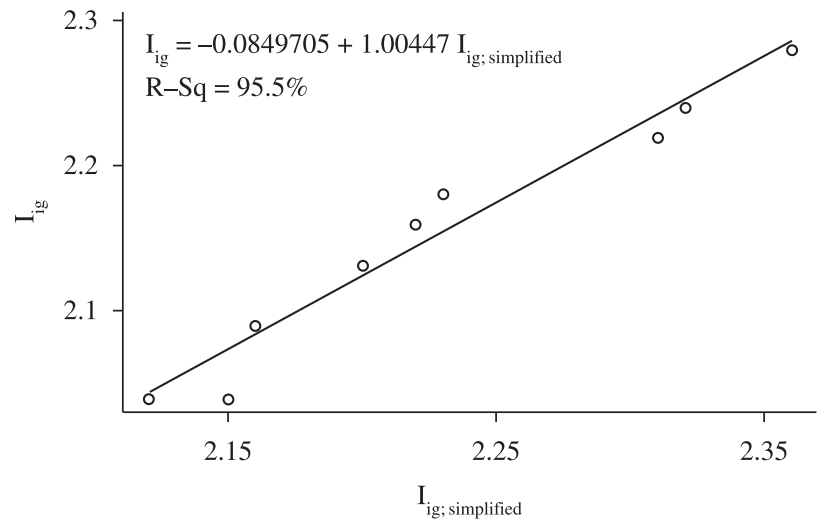

Figure 12. Regression between $I_{i g}$ and $I_{i g ;}$ simplified for the cities of the least values of $I_{i g}$.

Table 6. Descriptic statistics of $\mathrm{I}_{\mathrm{ig}}$ e $\mathrm{I}_{\mathrm{ig} \text {; simplified }}$.

\begin{tabular}{lcc}
\hline \multicolumn{1}{c}{ Statistics } & $\mathrm{I}_{\mathrm{ig}}$ & $\mathrm{I}_{\mathrm{ig} ; \text { simplified }}$ \\
\hline Mean & 2.48 & 2.60 \\
Minimum & 2.04 & 2.12 \\
Maximum & 2.85 & 2.86 \\
Amplitude & 0.81 & 0.74 \\
\hline
\end{tabular}

Table 7. Representative climatic index for four classes of aggressiveness.

\begin{tabular}{ccc}
\hline Decay region & Representative $\mathrm{I}_{\mathrm{ig} ; \text { simplified }}$ & Number of cities \\
\hline A & 0.5 & 0 \\
B & 1.5 & 0 \\
C & 2.5 & 28 \\
D & 3.0 & 74 \\
\hline
\end{tabular}

Table 8. Descriptive statistics of the parameters of the populations of $\mathrm{I}_{\mathrm{ig} ; \text { simplified }}$

\begin{tabular}{|c|c|c|c|c|}
\hline Statistics & \multicolumn{2}{|c|}{$\begin{array}{c}\text { Temperature } \\
\left({ }^{\circ} \mathrm{C}\right)\end{array}$} & \multicolumn{2}{|c|}{$\begin{array}{l}\text { Precipitation } \\
\quad(\mathrm{mm})\end{array}$} \\
\hline- & $\mathrm{I}_{\mathrm{ig} ; \text { simplified }<2.50}$ & $\mathrm{I}_{\mathrm{ig} ; \text { simplified }>2.50}$ & $\mathrm{I}_{\mathrm{ig} ; \text { simplified }<2.50}$ & $\mathrm{I}_{\mathrm{ig} ; \text { simplified }>2.50}$ \\
\hline Mean & 20.8 & 23.3 & 1393 & 1465 \\
\hline Minimum & 15.1 & 21.3 & 1167 & 1165 \\
\hline Maximum & 22.2 & 25.7 & 1726 & 2514 \\
\hline
\end{tabular}

Table 9. Coeficient values of the regressions $\mathrm{I}_{\mathrm{ig}} \times \mathrm{I}_{\mathrm{ig} \text {; simplified }}$.

\begin{tabular}{|c|c|c|c|}
\hline \multirow{2}{*}{ Regression } & \multicolumn{2}{|c|}{ Coeficient } & \multirow{2}{*}{$\begin{array}{c}\mathrm{r}^{2} \\
(\%)\end{array}$} \\
\hline & Linear (a) & Angular (b) & \\
\hline $\mathrm{I}_{\mathrm{ig}} \times \mathrm{I}_{\mathrm{ig} ; \text { simplified }}($ Figure 9) & 0.208034 & 0.874643 & 83.3 \\
\hline $\mathrm{I}_{\mathrm{ig}} \times \mathrm{I}_{\mathrm{ig} ; \text { simplified }}\left(\right.$ greater $\left.\mathrm{I}_{\mathrm{ig}}\right)$ & 1.73412 & 0.3621805 & 36.6 \\
\hline $\mathrm{I}_{\mathrm{ig}} \times \mathrm{I}_{\mathrm{ig} ; \text { simplified }}\left(\right.$ smallerI $\left._{\mathrm{ig}}\right)$ & -0.0849705 & 1.00447 & 95.5 \\
\hline
\end{tabular}


value the dispersion of data around the regression of the straight line $\mathrm{t}$ is high.

Appling Equation 16, which is the regression for the tem smallest

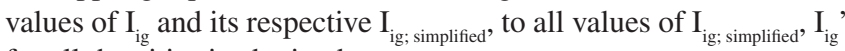
for all the cities is obtained.

$$
I_{i g}^{\prime}=1,00447 \times I_{i g ; \text { simplified }}-0,0849705
$$

(Equation 16)

Subtracting the value of Iig' from Iig the Error (e) of the estimate is gotten, as Equation 17. Through these the value of the Mean Error $\left(\mathrm{E}_{\mathrm{m}}\right)$ of the estimate is determined, Equation 18.

$$
\begin{aligned}
& E=I_{i g}-I_{I g}^{\prime} \\
& E_{m}=\sum_{i=l}^{n} \frac{I_{i g}-I_{I g}^{\prime}}{n}
\end{aligned}
$$

The value of the Mean Error $\left(\mathrm{E}_{\mathrm{m}}\right)$ is of -0.0438074 . Adding this value to the Equation 16, the final model adjusted is obtained to the data of the State of São Paulo, which will be called Climatic Index of the State of São Paulo for timber decay in contact with the ground.

$$
\begin{array}{ll}
I_{L L-S P}=1,00447 \times I_{i g ; \text { simplified }}-0,0849705-0,0438074 & (\text { Equation 19) } \\
I_{L L-S P}=1,00447 \times I_{i g ; \text { simplified }}-0,12878 & (\text { Equation 20) }
\end{array}
$$

Thus two models are proposed, the simplified model (Equation 21) which was shown to have small variation from the initial Leicester's model, and the model adjusted for the State of São Paulo (Equation 22).

$$
\begin{aligned}
& I_{\text {ig; simplified }}=f\left(R_{\text {mean }}\right)^{0,3} \times g\left(T_{\text {mean }}\right)^{0,2} \\
& I_{L L}=1,00447 \times f\left(R_{\text {media }}\right)^{0,3} \times g\left(T_{\text {media }}\right)^{0,2}-0,12878 \\
& f\left(R_{\text {media }}\right)= \begin{cases}0 & \text { Se } R_{\text {mean }} \leq 250 \mathrm{~mm} \\
f_{0}\left(R_{\text {media }}\right) & \text { Se } R_{\text {mean }}>250 \mathrm{~mm}\end{cases} \\
& f_{0}\left(R_{\text {media }}\right)=10 \times\left[1-e^{-0,001\left(R_{\text {media }}-250\right)}\right] \\
& g\left(T_{\text {media }}\right)= \begin{cases}0 & \mathrm{Se}_{\text {media }} \leq 5^{\circ} \mathrm{C} \\
-1+0,2 \times T_{\text {media }} & \mathrm{Se} 5<T_{\text {media }} \leq 20^{\circ} \mathrm{C} \quad(\text { Equation 25) } \\
-25+1,4 \times T_{\text {media }} & \mathrm{SeT}_{\text {media }}>20^{\circ} \mathrm{C}\end{cases}
\end{aligned}
$$

\section{Conclusions}

The possibility of a greater and better rational use of the timber necessarily passes through the attainment of a better knowledge of how this material behaves with elapsing of the time.

The models of timber degradation represent a form to quantify the effect of the environment in the process of decay for the regional climatic conditions.

Appling the initial model of degradation of timber in contact with the ground $\mathrm{I}_{\mathrm{ig}}$, and carrying through analyzes of the variables
Temperature, Precipitation and Dry Months, for the populations of $\mathrm{I}_{\mathrm{ig}<2.50}$ and $\mathrm{I}_{\mathrm{ig}>2.50}$, it was concluded that it does not exist statistical evidences of difference of these two populations for the variable Dry Months.

Carrying through the simplification of the initial model, and determining the values of $\mathrm{I}_{\mathrm{ig} \text {, simplified }}$, the population of these values with the population of $I_{i g}$ can be compared, not getting statistical evidences that indicate difference in these two populations of climatic indices.

The best regression between $\mathrm{I}_{\mathrm{ig}}$ and $\mathrm{I}_{\mathrm{ig} \text {; simplified }}$ is the one carried through between the ten smaller values of $I_{i g}$ and its respective $I_{\text {ig; simplified }}$, this being the closest to the straight line identity. Through this regression it was possible to propose an adjusted final model of climatic index of timber decay in contact with the ground, the $\mathrm{I}_{\text {LL-SP. }}$ This model is adjusted to the data of the State of São Paulo, which does not possess the necessity of the $\mathrm{N}_{\mathrm{dm}}$ variable (dry months) with the attainment of approximately the same obtained initial values through Leicester's Model. Thus two alternative models to the initial one are possible, the one of Leicester: the $\mathrm{I}_{\mathrm{ig} \text { s simplified }}$ and the $\mathrm{I}_{\mathrm{LL}-\mathrm{SP}}$.

For the analyzed data the simplification of Leicester's model can be considered as adequate.

\section{Acknowledgements}

We thank IAC - Agronomic Institute of Campinas, pertaining agency to the Secretary of Agriculture and Supplying of the State of São Paulo, for the supply of the climatic data.

\section{References}

1. Wolfe RW. Round timbers and ties. In: United States Department of Agriculture - USDA. Wood handbook: wood as an engineering material. Madison: USDA; 1999. p. 18.1-18.9. General technical report FPL - 113 .

2. Mehta PK and Monteiro PJM. Estruturas de concreto. São Paulo: Pini; 1994.

3. Manzin E and Vezzoli CO. Desenvolvimento de produtos sustentáveis. São Paulo: Edusp; 2005.

4. Fusco PB. Os caminhos da evolução da engenharia das madeiras. In: Anais do $3^{\circ}$ Encontro Brasileiro de Madeira e Estruturas de Madeira; 1989; São Carlos - SP, Brasil. São Carlos: LaMEM/EESC/USP; 1989. p. 7-18.

5. Cavalcante MS. Deterioração biológica e preservação de madeiras. São Paulo: IPT; 1982

6. Instituto de Pesquisas Tecnológicas - IPT. Biodeterioração de madeiras em edificações. São Paulo; 2001.

7. Highley TL. Biodeterioration of wood. In: United States Department of Agriculture - USDA. Wood handbook. Madison: Forest Products Laboratory; 1999. p. 13.1-13.5.

8. Leicester RH. Engineered durability for timber construction. Highett: CSIRO; 2001. $12 \mathrm{p}$.

9. Leicester RH, Wang CH, Nguyen MN, Foliente GC and Mckenzie C. An engineering model for the decay of timber in ground contact. In: Proceedings $34^{\circ}$ Annual Meeting of The International Research Group On Wood Preservation; 2003; Brisbane-Austrália, Stockholm, Suécia; 2003. $21 \mathrm{p}$.

10. Paes A, Camargo DE, Pinto HS, Brunini O, Pedro Jr. MJ, Ortolani AA, Alfonsi RR. Conceituação. [cited 2007 Jul. 24]. Available from: http://www.ciagro.sp.gov.br/clima. . 
Appendix 1. List of abbreviations.

Abreviations

\begin{tabular}{|c|c|}
\hline $\mathrm{CCA}$ & Chromated Copper Arsenate \\
\hline$\Delta \mathrm{D}$ & Variation of diameter \\
\hline NBR & Registered Brazilian Standard \\
\hline AS & Australian Standard \\
\hline Af & Humid tropical Climate \\
\hline Aw & Tropical Climate with dry Winter \\
\hline $\mathrm{Cfa}$ & Humid tempering Climate with hot Summer \\
\hline $\mathrm{Cfb}$ & Humid tempering Climate with tempering Summer \\
\hline Cwa & Humid tempering Climate with dry Winter and hot Summer \\
\hline $\mathrm{Cwb}$ & Wet tempering Climate with dry Winter and tempering Summer \\
\hline $\mathrm{I}_{\mathrm{ig}}$ & Climatic Index for timber decay in contact with the ground \\
\hline $\mathrm{I}_{\mathrm{ig}<2,50}$ & Value de $\mathrm{I}_{\mathrm{ig}}$ smaller than 2,50 \\
\hline $\mathrm{I}_{\mathrm{ig}>2,50}$ & Value de $I_{\text {ig }}$ greater than 2,50 \\
\hline $\mathrm{I}_{\mathrm{ig} ; \text { simplified }}$ & Simplified Climatic Index for timber decay in contact with the ground \\
\hline $\mathrm{I}_{\mathrm{ig} ; \text { simplified }<2,50}$ & Simplified Climatic Index smaller than 2,50 \\
\hline $\mathrm{I}_{\mathrm{ig} ; \text { simplified }>2,50}$ & Simplified Climatic Index greater than 2,50 \\
\hline$I_{L L-S P}$ & Climatic Index in São Paulo State for timber decay in contact with the ground \\
\hline $\operatorname{lag}_{\text {un, heart, stake }}$ & Initial period of decay for the experimental non-treated heartwood stakes \\
\hline $\operatorname{lag}_{\text {un, core, stake }}$ & Initial period of decay for the experimental non-treated core wood stakes \\
\hline $\operatorname{lag}_{\text {un, sap, stake }}$ & Initial period of decay for the experimental non-treated sapwood stakes \\
\hline $\mathrm{r}_{\mathrm{un}, \text { heart, stake }}$ & Speed of decay for the experimental non-treated heartwood stakes \\
\hline $\mathrm{r}_{\text {un, core, stake }}$ & Speed of decay for the experimental non-treated core wood stakes \\
\hline $\mathrm{r}_{\text {un, sap, stake }}$ & Speed of decay for the experimental non-treated sapwood stakes \\
\hline
\end{tabular}

